\title{
The Upper Part of the Una River Valley Between Martin Brod and Pritoka - Geomorphological Characteristics
}

\author{
Andrija Bognar
}

\begin{abstract}
The Una River Valley has complex characteristics defined by the interchange of gorges, basins and valley extensions. The river has adapted itself to the primary geologic structure and to the activity of tectonic movements. The longitudinal profile of the river is the result of numerous rapids, cascades and waterfalls, the formation of which is connected with calcareous sinter accumulation. Morphogenetic analysis has shown that a series of very attractive and strange relief forms is being formed in the riverbed of the River Una such as calcareous sinter barriers, sinter riverbeds, calcareous sinter islands and caves.
\end{abstract}

Key Words: Una River, calcareous sinter, riverbed, micro-landforms

\section{Geomorfološke karakteristike gornjeg dijela doline Une između Martin Broda i Pritoke \\ Kompleksnost doline rijeke Une očituje se u izmjeni sutjeski, zavala i kotlina. Rijeka se prilagodila primarnoj geološkoj strukturi i tektonskoj aktivnosti. Uzdužni profil rijeke rezultat je brojnih brzaca, kaskada i vodopada, čije je oblikovanje povezano s taloženjem sedre. Mofrogenetska analiza je pokazala da se u koritu rijeke Une stvara niz vrlo atraktivnih i neobičnih oblika: sedrene barijere, sedrena riječna korita, sedreni otoci i spilje.}

Ključne riječi: rijeka Una, sedra, riječno korito, mikro reljef

\section{INTRODUCTION}

The area of the Una River Basin (topographic and hydrological) figures out at $9,640 \mathrm{~km}^{2}$ (Spahić, 2000). The Upper Una River Valley from the spring near Suvaja (in the Republic of Croatia) to Bihać (Bosnia and Herzegovina), in geomorphologic view, belongs to the megageomorphologic entity of the Dinaric Mountain System, and to the macrogeomorphologic entity of Western Bosnia's wide ridges and poljes (Bušatlija, 1982) as well as to Mountainous Croatia (Bognar, 2001). It consists of mezoregions similar in morphostructural and morphogenetic sense: in Bosnia and Herzegovina, going from the SE towards the NW, they are: the regions of the Mountain Chain Jadovnik-Bobare-Sjenica, then the Region of the Mountain Range Osječenica with the Mountain Group of Ljutoč and Una Basin, as well as the regions of the Grmeč Mountain Group. In the Republic of Croatia, we can mention the mezogeomorphologic regions of the Lička Plješivica Mountain 
Group. The Upper Una Valley mainly belongs to the mezoregions Osječenica with the Mountain Group of Ljutoč and Una Valley, as well as to the Lička Plješivica Mountain Group. Subgeomorphologic units consist of homogenous geomorphologic micro-relief entities, which more or less differ in orographic and structural sense. ${ }^{1}$

1. Mezoregional entity: Osječenica Mountain Range with the Ljutoč Mountain Group and Una Valley

1.1. Subregion: Osječenica Mountain Range

1.1.1. Microregion: Central Range of

Osječenica with SW and NE

Pediments

1.1.2. SW Osječenica - Čavla Mountain Range

1.1.3. SE Range of Osječenica with the Pediment

1.1.4. Lupina Mountain Block

1.1.5. Bjelajsko Polje Basin

1.1.6. Kulen Vakuf-Klisa extension of Una Valley

1.1.7. Hilly Region of Havala
1.2. Subregion: Ljutoč Mountain Group with Una Valley

1.2.1. Microregion: LjutočVijenac Mountain Range with the Pediment

1.2.2. Microregion: Dulibe Dry Valley

1.2.3. Mountain Massif of Veliki Ljutoč with its Pediment

1.2.4. Račić Hilly Region

1.2.5. Una River Gorge Between Kaluđerica and Lohovo

2. Mezoregional entity: Grmeč Mountain Group with a Series of Basins, Karst Poljes and Una Valley

2.1. Subregion: NW Part of the Grmeč Mountain

2.1.1. Microregion: Jadovnica Mountain Massif

2.1.2. Mountain Range of Trovrha

2.1.3. Karst Denudational Plain of Grabež

2.1.4. Una River Valley Between Ripač and Pritoka
2.2. Subregion: SE Part of the Grmeč Mountain Group with a Series of Basins and Dry Valleys

2.2.1. Microregion: SE Grmeč Mountain Range

2.2.2. Javornjača Mountain Massif

2.2.3. Krnjeuša Dry Valley

2.2.4. Petrovačko Polje Basin

3. Mezoregion: Lička Plješivica with the Poštak Mountain Massif (Bognar, 2001)

3.1. Subregion: NW Mountain Range-Goli Vrh

3.1.1. Microregion: Međeđak Hilly Region

3.1.2. Gola Plješivica Mountain Range

3.1.3. NE Pediment of Gola Plješivica

3.1.4. Lohovo Hilly Region with Una Valley
3.2. Subregion: Mountain Group of Plješivica`s

Central Part

3.3. Lapačko Polje Basin and Hilly Regions with Mountain Ridges Visočica, Lisac and Pediment Kalati

3.3.1. Microregion: Series of Mountain Ridges of Visočica and Lisac with Pediments (Kalati)

3.3.2. Series of Mountain Ridges Basača - Trovrsi V. Oštrelj 


\section{General morphologic characteristics}

The area of the Upper Una River Basin is a typical mountainous region characterized by mutually parallel sequences of block mountain (Ljutoč 1,168, Bobare 1,267 m, Sjenica $1,113 \mathrm{~m}$ ) and high mountain ranges, massifs and ridges, as well as by numerous intermontane basins (of Bihać, Martin Brod, Drvar, etc. , 200-1,100 m), river valleys and dry valleys (Una, Unac, etc.) generally elongated in the Dinaric direction: NW-SE.

Tab. 1 Relative relief

Tab. 1. Energija reljefa

\begin{tabular}{|c|c|c|}
\hline classes & area $\left(\mathrm{km}^{2}\right)$ & area (\%) \\
\hline to 5 & 0 & $0.0 \%$ \\
\hline 5 to 30 & 0 & $0.0 \%$ \\
\hline 30 to 100 & 2 & $0.9 \%$ \\
\hline 100 to 300 & 87 & $39.0 \%$ \\
\hline 300 to 800 & 133 & $59.6 \%$ \\
\hline more than 800 & 1 & $0.4 \%$ \\
\hline
\end{tabular}

Tab. 2 Slope Inclination

Tab. 2. Nagib padine

\begin{tabular}{|c|c|c|}
\hline classes & area $\left(\mathrm{km}^{2}\right)$ & area (\%) \\
\hline to 2 & 31.88 & $14.1 \%$ \\
\hline 2 to 5 & 22.2 & $9.8 \%$ \\
\hline 5 to 12 & 60,56 & $26.8 \%$ \\
\hline 12 to 32 & 90.36 & $40.1 \%$ \\
\hline 32 to 55 & 20.36 & $9.0 \%$ \\
\hline more than 55 & 0.2 & $0.1 \%$ \\
\hline
\end{tabular}

As a rule, the mountainous ranges and ridges are linearly elongated and arced elevations, while mountain massifs have an isometric outline. Intermontane basins have a similar outline. Average relative relief varies from $300-800 \mathrm{~m} / \mathrm{km}^{2}$, while a smaller one is characteristic only for basins and hilly regions, as well as for pediments. Consonant with especially great relative relief, steep $\left(12^{\circ}-32^{\circ}\right)$ and very steep slopes $\left(32^{\circ}-55^{\circ}\right)$ dominate, and the escarpments over $55^{\circ}$ are very frequent as well. The areas of more gentle slopes $\left(0-2^{\circ}, 2^{\circ}-5^{\circ}\right)$ characterize the basin, valley and dry valley bottoms, as well as somewhat more dissected hilly regions and pediments $\left(5^{\circ}-12^{\circ}\right)$. We can distinguish the following types of orographic structures: valleys with smaller basins, dry valleys, basins, hilly regions, mountain ranges, massifs and asymmetrical ridges with pediments. 


\section{Structural geomorphologic and geologic characteristics (relation of relief and geologic structure)}

In the most recent neo-tectonic stage, during the Pliocene and Quaternary, the changes in the tectonic thrust - stress of the Adriatic micro-plate (a part of the larger African lithosphere plate) from the direction SW-NE to the direction S-N to SSE-NNW caused changes in kinematics of geologic structure movements, as well as those in development of relief forms, which adapted to new circumstances. That can be seen in compression and extension processes, retrograde movements of geological structures, emergence of new and revival of some old faults. The emergence of horizontal (strike-slip) movements dependent on the thrust-stress angle (up to $30^{\circ}$ ) is also characteristic. It had and has some reflection on relief. Transversal valleys directed S-N, SW-NE and W-E develop in this connection. At the same time, some older pull-apart structures (e.g. Basin of Bihać, Basin of Drvar and the basin which existed in the area of the present geomorphological subregion: The Ljutoč Mountain Group with the Una River Valley) lessened and closed because of compression, or experienced a complete tectonic inversion (subsidences became series of elevations). It relates to the Una River Valley, specifically to its spring part down to the Basin of Bihać. Owing to that, during a more recent neo-tectonic stage, the valley's present composite structure was formed. It is defined by an interchange of valley extensions and smaller basins with gorges as well as by numerous elbow-like flow deviations. Consonant with that, all mentioned more recent tectonic movements were decisive for the ormation of the present-day orographic (relief) structure of the Una River Valley in the researched area.

\section{Recent structural complex and contemporary structural-geomorphologic char- acteristics $^{2}$}

The researched area is situated in the framework of the regional structural unit: Dinaric (Herak, 1991), a part of the Dinarides Mountain System (Bognar, 1990). The principal structural characteristic of the area is its marked fragmentation with the stretching of structures and faults NW-SE, prevailingly NNW-SSE. Three structural units are most important; the enclosed map of the recent structural complex includes only their border parts: Plješivica (1), Grmeč (2) and Osječenica (3). The area between those units is especially remarkable; there are seven local uplifted structures (mountain ranges, massifs, hilly regions). It is important to point out that reverse-faults stretch along the wings of those structures. In relief, structural units are represented by the mountains stretching NW-SE, and local uplifted structures by smaller, most frequently separated hilly regions (hills) stretching prevailingly NNW-SSE, and southwards of Martin Brod NW-SE.

Faults play the most important role in the structural complex, especially those bordering on structural units. They are represented by zones of different stretch: the fault Ličko Petrovo Selo-Bihać-Martin Brod (1-reverse, vergence towards the NE and ENE, then southwards of Martin Brod towards the SE; the stretch of the narrower zone by V. Skočaj reaches $1,500 \mathrm{~m}$; the principal faults are followed by branches, also reverse-faults visible near V. Skočaj, Nebljus and westwards from Kulen Vakuf), then the Grmeč fault (2-reverse, vergence towards the SW), and Drvar fault (3-reverse, vergence towards the WSW, and towards the SW between Martin Brod and Drvar; the zone stretch up to $600 \mathrm{~m}$; steep faults along Osječenica are followed by marked branches). 
The faults bordering with local uplifted structures are especially prominent. They are prevailingly reverse, bend along their stretching line and often represent branches with opposite vergences on the surface. That points to the space compression. Besides, horizontal movements of the most prominent parts of local structures stand out. Local faults most frequently follow the most important faults of a structural complex. The faults of the NE-SW to E-W system are visible between particular faults of shorter stretch, in spots even traversed by them, especially southwards from Bihać, near Veliki and Mali Ljutoč, westwards from Orašac and in the wider zone parallel with Pištalska Draga near Kulen Vakuf.

It is important to point out their direct reflection in relief. E. g. escarpments stand out along the fault lines Ličko Petrovo Selo - Bihać - Martin Brod (1) southwards from Bihać, near Lohovo and Brotnje, and particular faults along the wings of the separated structures near Lohovo, between the valley of Orašac (Dulibe), Klisa and Kulen Vakuf. A high escarpment in the zone of the Drvar fault (3) between Baračuša and Kulen Vakuf is especially prominent. Straight and deep cut valleys emerge frequently, e.g. in the zone of the fault Bihać-Lohovo (4) and parallel especially with the faults of the system NE-SW to E-W. It is important to point out that the Una riverbed has also developed along the zones of particular faults, certainly conditioned by movements of the surrounding structures. Along the Una River Valley there are elbow-like anomalies in spots where faults traverse the riverbed, e. g. near Golubić, Loskun, Luka and Dalasenovac. A straight flow of the River Una parallel with the faults between Kulen Vakuf and Martin Brod is especially prominent.

Morpho-structural system dynamics is conditioned by regional tectonic movements. The structural unit movements depend particularly on them. Between them, depending on mass distribution of different density rocks, a stress field has been established. Maximal compressive stress (Anderson, Jackson, 1987; Grunthel, Stormeyer, 1992; Prelogović et al., 2001) is oriented between $320-140^{\circ}$ and $30-210^{\circ}$, most frequently $350-170^{\circ}$ and $10-190^{\circ}$. Such stress orientation is diagonal on stretching of structures and faults, which causes diagonal, often reverse movements of the fault wings in space. Only in some spots the stress is almost transversal or transversal on fault stretching, e.g. in the hilly region of Lohovo and local structure Veliki Vrh - Sjenica (5). This results in transversal reverse movements. Frequent orientation of compressive stress is at an angle of $30^{\circ}$ in relation to fault stretching. Then there are horizontal (strike-slip) movements of fault wings, e.g. near Bihać, Nebljus and, especially between Luka, Orašac and Klisa.

The following is most important: the mountain structure ofPlješivica(1) generally moves towards the SE because of tectonic movements, with various movements of its parts in spots. At the same time, the structure of the Grmeč Mountain Massif (2) and that of the Osječenica Mountain Range (3) move towards the SW, S and SE because of rotation. Such movements of structural units cause compression of the space between them and closing of the former large pull-apart structure, which was developed in the Miocene. In this connection, the presence of the right tectonic transport of structural units is very important. The movements of structural units cause development of the uplifted local structures (pop-up type) in the space between them (Hilly Region of Lohovo, mountain massifs Veliki i Mali Ljutoč and mountain ranges Vijenac, Ljutoč and Basaća), along whose wings reverse faults of opposite vergences develop. Parallel, there are right diagonal, in places horizontal (strike-slip) movements of fault wings. Therefore, here and there smaller basins - dry valleys (e.g. Mali Račić, Luke, Suvaja) or larger valleys (e. g. Orašac) develop and there is possible stretching or narrowing of the Una riverbed. 


\section{The Una River and its Tributaries Valley}

Generally, the Una River springs by the village Suvaja in Lika (Social Republic of Croatia) and flows to the settlement of Bihać (length: $75.72 \mathrm{~km}$, i. e. $66.2 \mathrm{~km}$ ) in the direction of SE-NW. The river fall on that sector accounts for $2,351 \mathrm{~m}$ on $\mathrm{km}$ or $2.35 \% \mathrm{o}$. However, we must point out that the river flows almost in meridian direction of SSE-NNW from the confluence with its right tributary Krka to Martin Brod (cca $7.6 \mathrm{~km})$. The Una River and its Tributaries Valley represents a composite valley, which is, in its longitudinal profile from Martin Brod to Bihać (52.5 km), marked with an interchange of gorges, very narrow valley sectors of transversal $\mathrm{V}$ profile and a series of larger and smaller valley extensions and basins. De facto, the river has conformed to the geologic structure. It is not older than the Pleistocene. We can distinguish 14 characteristic sectors: The Martin Brod Basin with the Confluence of the Una and Unac, The Una River Narrow Valley of Transversal V Profile from Martin Brod to the Settlement of Gečet, The Kulen Vakuf Valley Extension, The Gorge of Buk, The Valley Extension of Klisa, The Gorge of the Una River from Kaluđerica to Ledenik, The Una River Valley near the Settlement of Čelija, The Gorge of Štrbački Buk to Rudenjak, The Una River Valley from Rudenjak to Loskun, The Gorge of the Loskun Karst, The Una River Narrow Valley of Transversal V Profile to Lohovo, The Lohovo Valley Extension, The Valley Narrowing of Otok, The Ripač-Pritoka Valley Extension (as a part of the Bihać Basin).

\subsection{Riverbed - significance and development}

The riverbed morphology. The real longitudinal profile of the Una riverbed from its Karst spring near Suvaja (398,850 m of height above sea-level - Socialist Republic of Croatia) to Bihać $(220,160$ height above sea-level - Federation of Bosnia and Herzegovina), taking into consideration the heights above sea-level of the water gauge " 0 " point, represents a gentle concave curve. However, it does not show a homogenous course, but has some nicely marked fault escarpments. It is understandable, because it is a case of an inconsistent profile of the river flow. A balanced profile would anticipate the existence of a regular parabolic curve, on which every downstream profile point would correspond to the value of a smaller fall in relation to the upstream point.

Tab. 3 Longitudinal Profile of the Una River

Tab. 3 Uzdužni profil rijeke Une

\begin{tabular}{|l|c|c|c|c|}
\hline \multicolumn{1}{|c|}{ Water gauge station } & $\begin{array}{c}\text {,0“ el. point } \\
\text { in altitude }\end{array}$ & $\begin{array}{c}\text { Distance from } \\
\text { mouth in km }\end{array}$ & \multicolumn{2}{|c|}{$\begin{array}{c}\text { River fall } \\
\text { in m and \%o }\end{array}$} \\
\hline Source of Una & 398,850 & $218,7(208,7)$ & - & - \\
\hline Martin Brod-upstream & 362,990 & 195 & $35,86 \mathrm{~m}$ & $1,51 \% 0$ \\
\hline Martin Brod-downstream & 310,336 & 194 & $52,654 \mathrm{~m}$ & $26,33 \% 0$ \\
\hline Kulen Vakuf & 301,200 & 184,4 & $9,136 \mathrm{~m}$ & $0,95 \% 0$ \\
\hline Štrbački Buk-upstream & 292,670 & 168,0 & $8,5 \mathrm{~m}$ & $1,93 \%$ \\
\hline Štrbački Buk-downstream & 249,830 & 166,5 & $42,84 \mathrm{~m}$ & $17,4 \%$ \\
\hline Bihać & 220,160 & 142,5 & $29,67 \mathrm{~m}$ & $1,24 \%$ \\
\hline
\end{tabular}

Source: Vojno - inžinjerijski opis reke Une, FNR Jugoslavija, Državni sekretarijat za poslove narodne obrane, uprava inžinjerije, Beograd, 1960. 
Andrija Bognar - The Upper Part of the Una River Valley Between Martin Brod and Pritoka - Geomorphological Characteristics

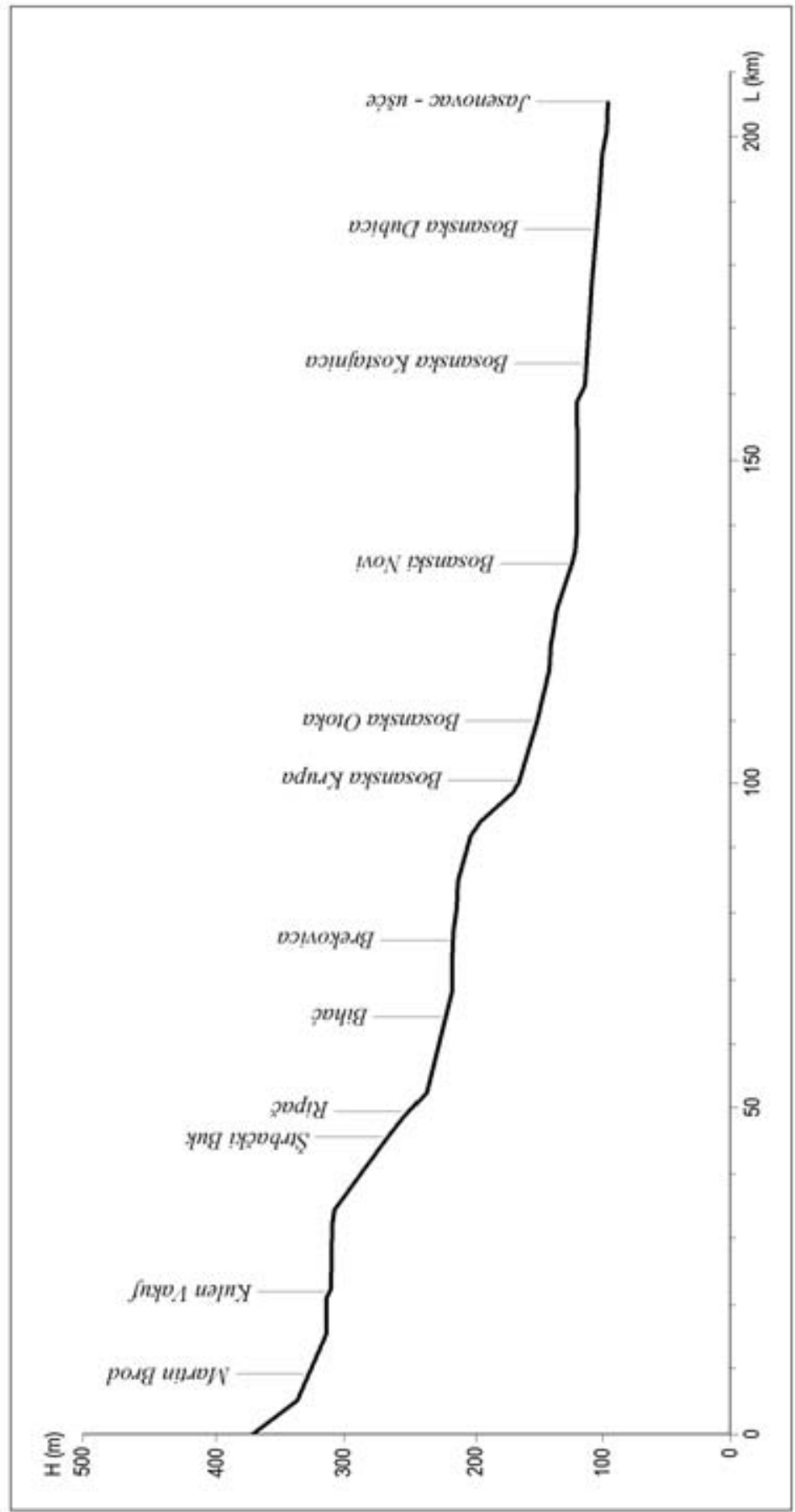

Fig.1 Longitudinal Profile of the River Una from the Spring to Mouth Sl.1. Uzdužni profil rijeke Une od izvora do ušća 
Tab. 4 The Una riverbed Dimensions in $\mathrm{m}$ and the Outflow Velocity in m/s from Martin Brod to Ripač Tab. 4 Dimenzije korita rijeke Une $(u \mathrm{~m})$ i brzina otjecanja vode $(u \mathrm{~m} / \mathrm{s})$ od Martin Broda do Ripača

\begin{tabular}{|l|c|c|c|c|c|c|c|c|c|}
\hline \multicolumn{1}{|c|}{ Water gauge } & \multicolumn{3}{|c|}{ Width in m } & \multicolumn{3}{c|}{ Depthu m } & \multicolumn{3}{c|}{ Velocity in m/s } \\
\hline & \multicolumn{3}{|c|}{ water level in cm } & \multicolumn{3}{c|}{ water level in cm } & \multicolumn{3}{c|}{ water level in cm } \\
\hline & low & middle & high & low & middle & high & law & middle & high \\
\hline Martin Brod & 25 & 35 & 52 & 1 & 2,7 & 4,5 & 1 & 2 & 3 \\
Kulen Vakuf & 60 & 101 & 110 & 1 & 1,9 & 5,5 & 1 & 1,5 & 2 \\
Strbački & 98 & 110 & 130 & 4 & 5,8 & 7 & 1,5 & 2 & 3,5 \\
$\begin{array}{l}\text { Buk- } \\
\text { downstream }\end{array}$ & 130 & 170 & 220 & 0,4 & 1,8 & 3 & 0,8 & 1,5 & 3 \\
Ripač & & & & & & & & & \\
\hline
\end{tabular}

Source: Vojno-inženjerijski opis reke Une, Beograd 1960.

1) In the Martin Brod Basin, $0.5 \mathrm{~km}$ downstream from the gorge to the fault escarpment Milančetov Slap (waterfall), the river flows with the characteristics of down flow; several riverbed extensions (3-5) have been formed with calcareous sinter islets and banks. Downstream from the Milančetov Slap to the confluence with the River Unac, the River Una cuts in by the upper flow water mechanism; its riverbed is full of banks and cascades.

2) In the narrow valley from Martin Brod to the settlement of Gečet the River Una has adapted to the geologic structure and flows almost in a straight line. Because of the small fall $(0.95 \% \mathrm{o})$ its riverbed was formed in calcareous sinter accumulations, gravels and sand. In spots, it meanders making calcareous sinter islets with backwaters. Accordingly, where the water does not form a lake upstream of the banks, it flows away by the middle flow mechanism.

3) In the Kulen Vakuf Valley Extension, the riverbed has an insignificant fall, it meanders (middle flow) and forms calcareous sinter islets with backwaters.

4) In the Gorge of Buk the river cuts in because of an increased fall downstream from the calcareous sinter barrier-cascade - the upper flow water mechanism.

5) Downstream in the Klisa Valley Extension, in concordance with the small fall of the riverbed $(<2 \%$ o), the River Una flows by the middle flow water mechanism and forms 3-4 meanders in mature development stage (Bognar, 1990). There are nicely formed ridges on the tops of the curves, as well as calcareous sinter banks on the convex side of the meander. The floodplain is comparatively wide. There have been determined the traces of the old riverbeds - curves - oxbows; they point to the lateral migration of the Una riverbed.

6) In the Una River's gorge from Kaluđerica to the extension by the settlement of Ćelija, the river flows almost in a straight line. Only one, tectonically predisposed curve has been developed. The riverbed is stable and cut in the perennial limestone rock - a gently marked mechanism of the upper flow waters.

7) The valley widens somewhat in the Ćelija settlement region. The Una River has adapted to the geologic structure there, so it makes a curve before its confluence with the stream Luka. The riverbed is stable, and because of the water support barrier - waterfalls and cascades by Štrbac, the river flows slowly, de facto, it makes a lake. 
8) The Štrbački Buk Gorge down to Rudenjak is characterized by the upper flow water mechanism. The River Una cuts in limestone there throughout the length of 2.5-3 $\mathrm{km}$ under the influence of a transversal fault, but, simultaneously, because of a specific separation of neutral $\mathrm{CaCO}_{3}$ caused by water dispersion and ventilation, accumulates calcareous sinter and models numerous waterfalls and cascades.

9) and 10) The Una riverbed from Rudenjak to Loskun and in the Gorge of Loskunski Kras is generally elongated in the Dinaric direction (NW-SE), but it also arches meandering "falsely" as the result of different recent thrust of the Lička Plješivica rock masses towards the SE. The floodplain is fragmentally developed. The riverbed is stable; cut in limestone by the upper flow water mechanism.

11) The Una riverbed from the Loskunski Kras Gorge to Lohovo meanders "falsely", de facto, often makes elbow-like bends because of an intensive tectonization of the area. The riverbed is stable and cut into the perennial carbonate rock - the river flows gently by a marked upper flow mechanism. Nevertheless, because of strong ventilation and making a lake, there is an intensive accumulation of calcareous sinter. Two smaller fault escarpments have been formed - the cascades of Troslap (theree waterfalls) and Dvoslap (two waterfalls) 2-3 $\mathrm{m}$ high, which cause the formation of numerous barriers with cascades.

12) and 13) From Gornje Lohovo the Una River turns from the Dinaric direction (NW-SE) of flowing to the direction of WSW-ENE under the influence of "younger" formation of the Lohovo hilly region pop-up structure. The riverbed has been formed in the river's flood material inside the Lohovo Valley Extension. It has a small fall and intensive calcareous sinter accumulation, which resulted in the formation of two smaller barriers with cascades, $0.5-1 \mathrm{~m}$ high, as well as in forming a lake in the riverbed upstream from the barriers. The river flows by a gently marked middle flow mechanism there, which can be clearly noticed by meander formation in the Otok valley narrowing.

14) In the Ripač-Pritoka Valley Extension, which is a part of a larger pull-apart structure - the Bihać Basin, the Una riverbed has an insignificant fall and accumulates chiefly the flood material and calcareous sinter; 9 banks (cascades) have been formed. The river flows mostly by the middle flow mechanism, which can be verified by the existence of oxbows («Pod Bukvom») down to Ripač, and further by the down flow water mechanism (emergence of old riverbeds and intensive sedimentation of calcareous sinter).

Development of c a l c e r o u s s in te r. Conditions necessary for calcareous sinter development: 1) Water must contain a certain quantity of calcium bicarbonate, 2) Appropriate temperature of the flowing water, 3) Existence of alive organisms who can retain carbonate sediments, 4) Appropriate water velocity.

1) The quantity of melted calcium bicarbonate is expressed by alkality, i. e. carbonate solidity expressed by German or French grades. According to the German hydro biologist Ohle (1937), carbonates accumulate in the waters with alkality of 1.3 , i. e. carbonate solidity of 4 HD . The Una River water has the alkality of 3.7-4, and carbonate solidity of 10.4-11.3 HD (Matoničkin, Pavletić, 1960). There are significant differences in relation to other Karstic rivers and lakes (Plitvička jezera, Krka, Mrežnica, Gacka, Unac - Matoničkin, 
Pavletić, 1960), but they all have enough melted calcium bicarbonate, because the measured values are above the alkality limit of sedimentation and the unmeltable $\mathrm{CaCO}_{3}-$ calcareous sinter can be extracted after ventilation.

2) Although some waters have enough melted calcium bicarbonate, they do not leave calcareous sinter sediments, because there are no favourable temperature conditions. Namely, relatively low temperatures (lesser than $14^{\circ} \mathrm{C}$ according to Ohle) prevent splitting of bicarbonate. The example is the River Unac, the Una's right tributary (in summer $10^{\circ} \mathrm{C}$, in winter frozen, Matoničkin, Pavletić, 1960). As to the Una River, its water's temperatures are near border values in summer $\left(13.2-14.8^{\circ} \mathrm{C}\right)$, and in winter, chiefly beneath them $\left(8-15^{\circ} \mathrm{C}\right.$ - according Matoničkin, Pavletić, 1960). Accordingly, there are no corresponding thermal assumptions on Unac for leaving calcareous sinter sediments, which has been affirmed by field research.

Compared with other streams in Karst, the River Una, because of relatively low temperatures of its water, has minor conditions for sedimentation although HD value is relatively great. Therefore, in the River Una calcareous sinter accumulates more slowly, which understands a slower pace of its accumulation.

3) The further factor accelerating calcareous sinter sedimentation are living organisms especially accommodated to specific hydrologic and geomorphologic conditions. Their basic function is to keep neutral carbonate sediments. Algae and moss are most important. As to animals, we must point out snails, larvas, coleopters, confiers, etc. (Matoničkin, Pavletić, 1960). Smaller calcareous sinter accumulations (lower barriers) lack higher vegetation. It is favourable for the development of calcareous sinter making existential communities, which live in light. On the contrary, the area of larger barriers, banks and islets, which is covered with higher vegetation (willow, poplar, bushes and brushwood) is favourable for the development of calcareous sinter making vegetation that lives in shadow.

4) Velocity of flowing water depends on flows, inclination and lithologic structure of the rock mass in which the riverbed is cut, then on its inclination and hydraulic laws of water flow (centripetal, centrifugal forces and Bahr`s law), as well as on quantity of accumulation. Consonant with that, velocity of water is greatest immediately beneath the surface of the water current, and declines towards the riverbed bottom and riverbanks. In that process, the living organisms stand only specific velocity of water circulation, which must be under the critical limit and river's working ability, more precisely, under the limit where erosion dominates over accumulation. We must say that water velocity influences the ventilation effect, which also accelerates the intensity of sedimentation. In principle, the critical limit, which enables calcareous sinter sedimentation in a particular case, is marked by emergence of rheophil animals. In our Karst rivers, the critical limit is somewhere between $0.5 \mathrm{~m} / \mathrm{s}$ to $3.5 \mathrm{~m} / \mathrm{s}$. The average values for the Una River amount to $0.5-1.5 \mathrm{~m} / \mathrm{s}$, and for the Unac River to $1.0-1.5 \mathrm{~m} / \mathrm{s}$. Accordingly, the water velocity factor on the rivers Una and Unac has a positive impact on colonization of rheophil organisms (Matoničkin, Pavletić, 1960). We note that such favourableness does not stimulate colonization of corresponding organisms on the Unac River. Besides, we must point out, that an intensified erosion of a stream's flow eliminates a possibility of rheophil animials emergence. 
Relief forms developed by sedimentation of calcareous sinter. A succession of specific relief structures is formed by accumulation of calcareous sinter. Their emergence is connected with the first cca $146 \mathrm{~km}$ of the Una River flow to the confluence with the River Sana through the mountainous region of the Dinarides, where prevail carbonate rock complexes, limestone and dolomites. Attractive, often bizarre, relief forms are especially characteristic for the River Una to Bihać, although they can also be found downstream to Bosanski Novi.
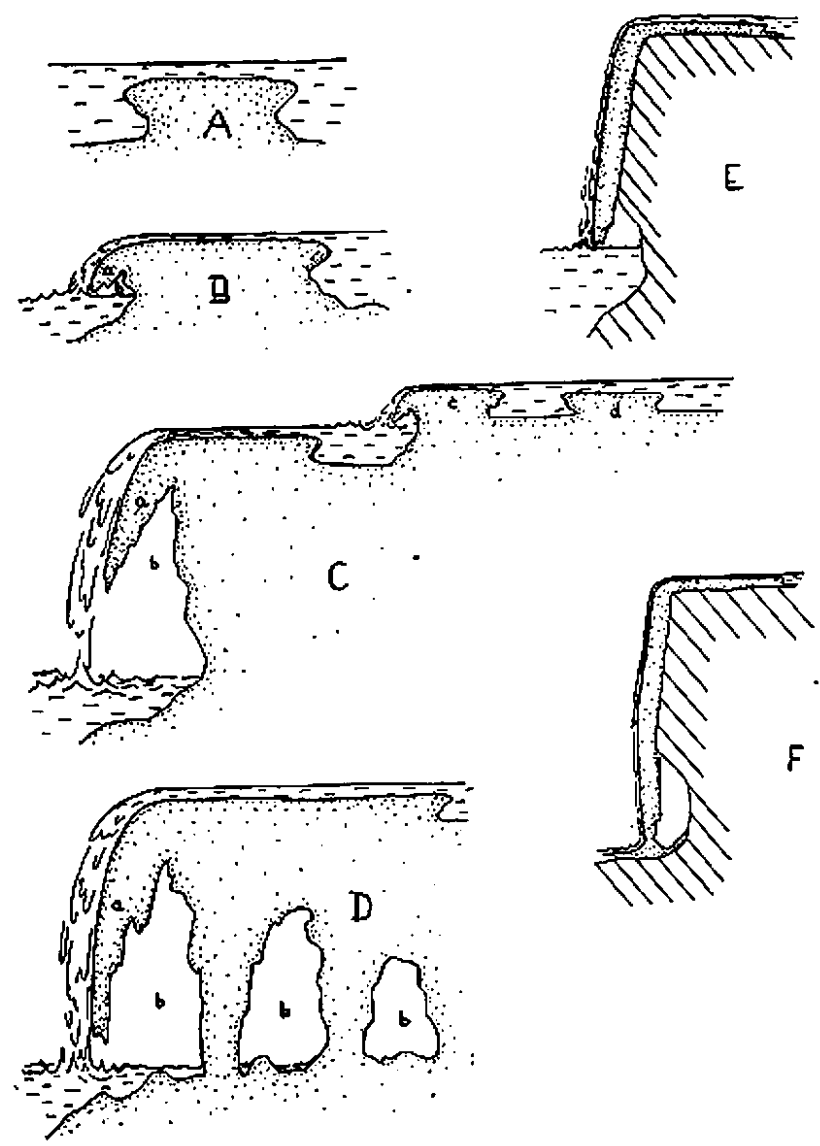

Fig. 2 Relief forms of calcareous sinter accumulations in the Una riverbed (taken from Pavletić, Z., 1960)

Sl. 2. Reljefni oblici sedrenih akumulacija u koritu rijeke Une (preuzeto iz Pavletić, Z., 1960)

Legend:
A) Calcareous sinter T bank
B) Small barrier
C) Barrier: a) Beard, b) Half-swallow hole (half-cave), c) Small barrier-cascade, d) T- bank
D) Cave system: a) Beard, b) Cave, E) Console, F) Calcareous sinter curtain

Legenda:

$\begin{array}{ll}\text { A) Sedreni } T \text {-prag } & \text { B) Barijerica }\end{array}$

C) Pregrada (barijera): a) brada, b) polupećina (poluspilja), c) pregradica - buk, d) T-prag

D) Sustav pećina (spilja): a) brada, b) pećina (spilja), E) Konsola, F) Sedreni zastor 


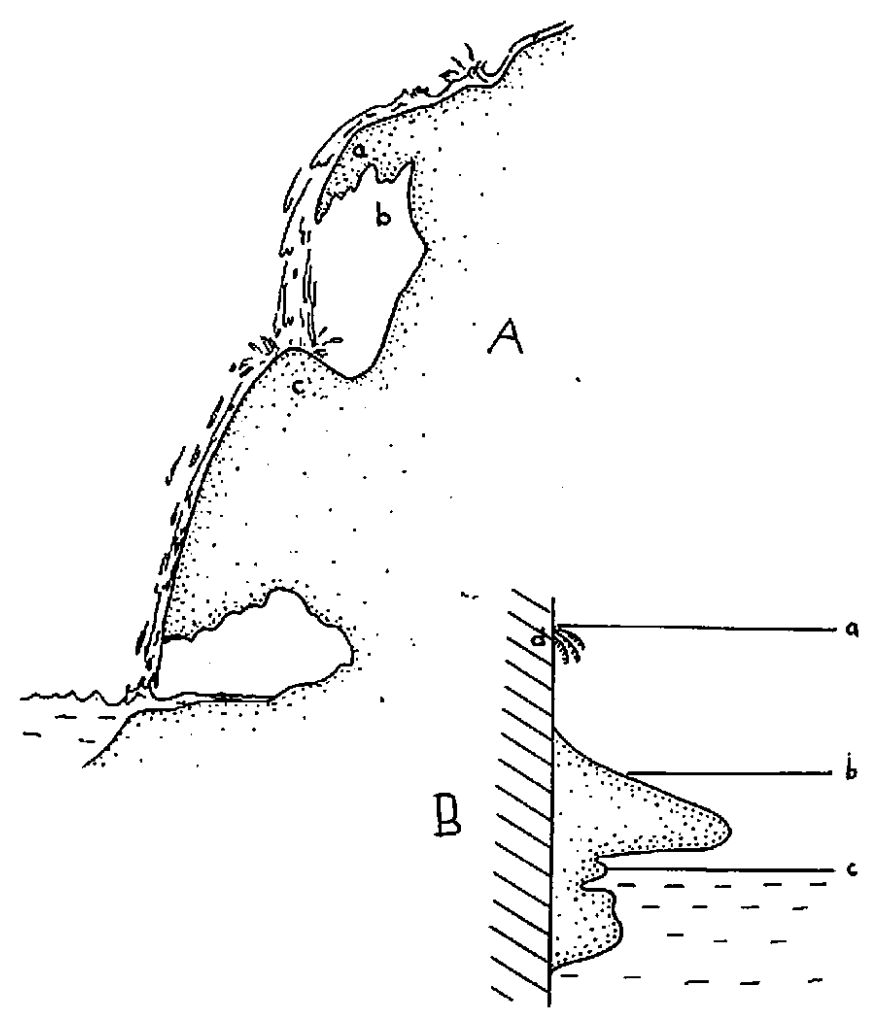

Fig. 3 Relief forms of calcareous sinter accumulation in the Una riverbed (taken from Pavletić, Z., 1960) Sl. 3. Reljefni oblici akumulacije sedre u koritu Une (preuzeto iz Pavletić, Z., 1960)

\section{Legend:}

A) Calcareous sinter cone: a) Beard, b) Half-cave, c) Cone

B) Calcareous sinter shelf: a) Maximum water level, b) Medium water level, c) Minimum water level,

d) Cinclidotus aquaticus zone

\section{Legenda:}

A) Sedreni čunj: a) brada, b) polupećina (poluspilja), c) čunj

B) Sedrena polica: a) razina visokog vodostaja, b) razina srednjeg vodostaja, c) razina niskog vodostaja d) Cinclidotus aquaticus zona

According to Matoničkin and Pavletić 81963) we can distinguish morphogenetic types of calcareous sinter: calcareous sinter small barriers, calcareous sinter banks and covers (islets), cascades, calcareous sinter banks with rapids and waterfalls.

1) Calcareous sinter small barriers (partitions) are most numerous. Their height varies from 0.5-1.5 $\mathrm{m}$. They have a specific structure and somewhat differ from those in other water flows in the Dinarides. While their barriers are characterized by the emergence of calcareous sinter beards downstream, such formations are weakly developed on the Una River. Just because of that, the small barriers downstream are almost vertical. However, we must note that in the past, when there was a more favourable climate, the Una had 
more calcareous sinter beards. But we shall talk about it later. There are also differences in barrier width. Namely, in other Karstic rivers barrier surface parts are narrow and short, but in the Una River, barriers are large in their surface part (some ten and more metres), in the downstream part they end with a " $\mathrm{T}$ " protrusion. The cause is, most probably, a small velocity of the Una water $(0.5-1 \mathrm{~m} / \mathrm{s}$ - Matoničkin, Pavletić, , 1963), which is not favourable to the formation of a bigger running water parabola over the banks. It slows down calcareous sinter sedimentation because of weaker ventilation of the water. Although small barriers and cascades look like younger relief forms, de facto, for their development they needed a longer period. Besides, a slowed down calcareous sinter accumulation is also conditioned by lower temperatures of water, which are not favourable to more intensive carbonate isolation from bicarbonate solutions. Such calcareous sinter barriers are most beautifully developed near Ripač, Bihać and further downstream near Grmuša and Bosanska Krupa.

2) Calcareous islets, inhabited by higher, even forest vegetation, of course, in the case when underwater calcareous sinter structures pass the water level. Development of such relief forms begins with the formation of underwater calcareous sinter islets, which represent small calcareous sinter banks and covers. They are connected with greater depths of the riverbed. Calcareous sinter sedimentation is conditioned by the existence of bluegreen algae, but a monocellular green alga Oocardium Stratum (Matonički, Pavletić, 1963) plays an important role. That means that the emergence of such calcareous sinter structures does not depend on dispersion and ventilation of water. The examples are the islands and banks near Martin Brod, Kulen Vakuf and somewhat more upstream from Ripač. In the basin extension of Martin Brod, after the gorge, a smaller calcareous sinter bank has been formed (10-20 m long), as well as six calcareous sinter islands between particular extensions of the Un River ( 75 to $160 \mathrm{~m}$ long and 40 to $70 \mathrm{~m}$ wide). There are two more islands downstream near Selište (350-475 m long, about $60 \mathrm{~m}$ wide - both islands are only partially calcareous sinter structures), three near Kulen Vakuf (70 to $275 \mathrm{~m}$ long, 30 to $90 \mathrm{~m}$ wide, also formed by sedimentation of calcareous sinter, gravel and sand, several downstream of Lohovo (3), Pod Bukvom, near Ključ and Golubić. Calcareous sinter banks emerge most frequently by lower water levels (Martin Brod, Kulen Vakuf, the Basin of Bihać).

3) Tectonically conditioned fault escarpments are the third relief type on which calcareous sinter accumulates. They are characterized by prominent inclinations, which cause the emergence of waterfalls. Water is being intensively ventilated, which leads to the isolation of big quantities of calcareous sinter. In the Basin of Martin Brod, The Una water pours down the succession (about $54 \mathrm{~m}$ long) of fault escarpments, calcareous sinter barriers, small barriers and cascades. The biggest one is Milanićev Buk - 10-12 m high, then somewhat lower Jalak and Donji Buk (Kapel, 2000). The Una has cut in calcareous sinter and some calcareous sinter blocks have been discovered in its riverbed, which points to the accumulation stage in the gorge in the time of larger flows or climate changes in the past (Postglacial period). Further downstream from the Luka stream floodplain, the Una River has formed its most beautiful gorge, so called Štrbački Buk, which can be followed some $3.25 \mathrm{~km}$ to the confluence with the stream Doljani near Rudenjak. In accordance with differentially marked tectonic thrusts towards the E and SSE, the longitudinal profile of 
the gorge has an arc outline; the rock complexes of Jurassic and Triassic dolomites have also been disturbed by a longitudinal fault NW-SE, along which there was a horizontal strike-slip movement of a fault wing in the SE direction. Owing to those tectonic relations, the Una flows through a deep gorge $(200-300 \mathrm{~m})$ with very prominent fault escarpments on its longitudinal profile near Strbac. $1.5 \mathrm{~km}$ between the elevation points " 0 " of the upstream and downstream water gauges, the Una has formed an impressive succession of waterfalls and cascades. The river fall figures out at $42.84 \mathrm{~m}$ or $17.4 \%$ o (Hidrološki odnosi..., knjiga IV, Sarajevo) ${ }^{2}$ which is, together with that near Martin Brod, the most prominent fault escarpment on the river's longitudinal profile from its source to the mouth. The riverbed water forms three calcareous sinter sections $40 \mathrm{~m}$ wide with the total height of $23.5 \mathrm{~m}$ (Spahić, 2000). They are especially impressive during big flows when they give the impression of a unique waterfall. Downstream of the largest waterfalls there is a succession of smaller calcareous sinter waterfalls - cascades 3-5 m high and rapids, which can be followed downstream to Rudenjak.

Fossil calcareous sinter often found in the riverbank zone could be accumulated only in the periods when there was little water in the riverbed, i. e. when erosion activity of the water was not revealed.

The emergence of caves, characteristic for other Croatian calcareous sinter-bearing river, has been determined only in Martin Brod at the level of the second calcareous sinter terrace and on Troslap. Vertical growth of small barriers on the downstream part of the river makes a small fall of water. Ventilation has the water parabola direction. A part of the small barrier hanging in the water fall direction like a beard is called beard (Pavletić, 1960 - according to Pevalek, 1953 and 1925). The space between beard and small barrier is called double chin. With time, beards become longer making real caves and half-caves out of double chins. As barriers or partitions grow, a whole system of caves can develop. If water ventilation in riverbed is happening on a longer section, calcareous covers can develop.

So-called calcareous sinter shelves are also very interesting. They develop as calcareous ledges in the water flow direction when water ventilation is also present (Pavletić, 1960). In his work about the River Krka (1960) Pavletić mentions specific calcareous sinter structures on the Roški Slap, so called calcareous sinter cones. Such micro-relief forms have been noticed on the Strbački Buk where the Una pours down by a waterfall more than 10 metres high on the base of conically accumulated calcareous sinter. A stream of water falls on the very top of the ledge, so that the water pours over its sides. As ventilation proceeds in the direction of the ledge's sloping sides, calcareous sinter grows in the same direction. Such forms Pavletić called (1960) calcareous sinter cones.

\section{River terraces}

As we have already mentioned dealing with the Una River Valley morphologic description, the river terraces emerge fragmentarily above the river's flow: I - the lowest and the youngest one, then follow II and III, which are, in principle, older. The emergence of the river terraces is not continued, neither is uniform the material structure they are made of. All three terrace-levels represent the traces of the former river valley plains. They are 
not flooded, so they represent drained areas, where settlements and main roads have developed. According to their heights over " 0 " elevation point of the water gauge and recent floodplain, all three terraces date from the Pleistocene. In material structure, we can find fluvial gravel and sand, as well as calcareous sinter. Emergence of calcareous sinter is a feature of the $\mathrm{I}^{\text {st }}$ terrace (near Martin Brod) and the $\mathrm{II}^{\text {nd }}$ one (near Martin Brod, Palučci, Klisa and Ripač $)^{3}$. We must say that the II $^{\text {nd }}$ terrace of the River Unac in the Martin Brod Basin was formed in the Pleistocene fluvial gravel. We think that the $\mathrm{I}^{\text {st }}$ Una's terrace developed by the end of the Pleistocene and in the Postglacial period, when there was a greater flow of the river and its erosion power caused by climate revolutionary changes (higher temperature and humidity, melting of glaciers), so it cut into the floodplain of the period; because of strong additional lateral erosion, the terrace is today preserved only in fragments, mainly at the altitude of 8-10 m above the recent floodplain. The II ${ }^{\text {nd }}$ Una's terrace is placed $20-25 \mathrm{~m}$ above the floodplain. It is chiefly made of calcareous sinter, except downstream of Kulen Vakuf, where it appears as an erosion floor. It represents a trace of a warmer interstitial period of the last glacial - Würm. It is evident that there were favourable assumptions for calcareous sinter accumulation, so the river valley was most probably filled with calcareous sinter barriers-cascades. That means that there were several lakes (Martin Brod, Palučci, Klisa, Ripač). Then followed a period of a changed climate characteristic for low temperatures and intensified erosion, so the river destroyed a greater part of previously accumulated calcareous sinter. Those calcareous sinter accumulations have remained only as terrace fragments $20-25 \mathrm{~m}$ above the floodplain. The highest III ${ }^{\text {rd }}$ terrace has been formed in calcareous sinter only near Martin Brod (on the height of 40 to $50 \mathrm{~m}$ ). Downstream (near Kulen Vakuf, Kaluđerica, Lohovo and Ripač) the terrace remained only as an erosion floor, connected with the perennial rock; traces of fluvial gravel have been found on the mentioned floor.

\section{NOTES}

1. The regionalization has been carried out in accordance with the basic principles of geomorphologic regionalization (Bognar, 2001). Morphostructural, morphogenetic, lithologic and orographic characteristics were used in hierarchical selection of particular regions on macro, mezo, sub and microgeomorphologic level. The hydrogeographic net was taken into consideration as a supplementary factor.

2. We are grateful to Eduard Prelogović, PhD, Full Professor at the Faculty of Geology and Petroleum Engineering in Zagreb for this subchapter analysis (with smaller supplements by academician Andrija Bognar), as well as for making of the enclosed map of the recent structural complex

3. Probably also on the other sites marked on the geomorphological map, but they have not been researched because of mine-fields (mine-field map $\mathrm{R}=1: 25.000, \ldots 2005$ ) 


\section{REFERENCES}

Anderson, H. Jackson, 1987, Active tectonics of the Adriatic Region, Geophysic Y.R., Astr. Soc.,91

Bognar, A. 1990, Geomorfologija Baranje, Posebna izdanja Geografskog društva Hrvatske, sv. 7, GDH, Zagreb

Bognar, A., 2001, Geomorfološka regionalizacija Hrvatske, Acta Geographica Croatica, Vo. 34 (1999), Geografski odsjek PMF-a, Zagreb, Zagreb

Bošnjak, R. 1938, Dolina Une, Glasnik GDH, sv. XXIV, Beograd

Bušatlija I., 1982, Oblici reljefa i geomorfološka regionalizacija B i H, Enciklopedija Jugoslavije br. 2, 2. izdanje, Jugoslavenski leksikografski zavod, Zagreb

Chorowiez J., 1977,Etude Geologique des Dinarides le long de la structure transversele Split-Karlovac. Soc.Geologique du Nord, 1, Villenueve d'Asgy

Cvijanović D., Prelogović E., Kranjec V., Skoko D.,Zagorac Ž., Bahun S.,Oluić M.,1979, Seizmotektonska karta Hrvatske i susjednih područja. Arhiv Geofizičkog zavoda PMF-a, Zagreb

Dimitrijević, M. i ostali, 1979, Osnovna geološka karta 1:100.000, Tumač za list Bosanska Krupa, SFRJ, Beograd

Grunthel G., Stormeyer D., 1992, The recent crustal stress field in Central Europe. Trajectories and finite element modeling, Journal. Geophysic R., 97/B8

Herak M., 1991, Dinarides. Mobilistic vie of the genesis and structure. Acta geologica 21/2, Zagreb

Kapel, A., 2000, Prijedlog proglašenja rijeke Une NP i upis u listu svjetske kulturne i prirodne baštine UNESCO, Bihać

Karta minskih polja $\mathrm{R}=1: 25.000, \mathrm{BH}$ MAC, Sarajevo, mart 2005. godine

Marković M., 1983., Osnovi primjenjene geomorfologije, Geoinstiut, Beograd

Matoničkin, I., Pavletić ,Z., 1960, Biološke karakteristike sedrenih slapova u našim krškim rijekama, Geografski glasnik br. 22, GDH, Zagreb

Matoničkin, I., Pavletić, Z., 1963, Sedrene naslage u rijeci Uni i njihova biološka uvjetovanost, Geografski glasnik br. 25, GDH, Zagreb

Moičević M., Maksimčev S., Vrhovčić J., 1977, Osnovna geološka karta, list Bosanska Krupa 1:100.000, L 33 - 117, Institut za geološka istraživanja Sarajevo, Savezni geološki zavod, Beograd

Ohle, W., 1937, Kalsystematic unserer Binnengewässer un der kalkgehalt, Rügener Bache, Geologie der Meere und Binnengewässer Bd., I. H. 43

Orijentaciona vodoprivredna osnova sliva rijeke Une, Geološke, hidrografske, hidrološke i geodetska podloge, knjiga 4, «Hidrološki odnosi u slivnom području Une», bez godine, Srajevo

Pavletić, Z., 1960, Sedreni slapovi rijeke Krke, Njihov postanak, Krš Jugoslavije 2, Zagreb

Pavletić, Z., 1969, Važnost sedrene barijere za održavanje prirodnih akumulacija površinskih voda u kršu, Krš Jugoslavije 6, Zagreb

Pevalek, I., 1925, Oblici fitogenih inkrustacija i sedre na Plitvičkim jezerima i njihovo geološko znamenje, Spomenica u počast prof. dr. Gorjanović-Kramberger, Zagreb

Pevalek, I., 1953, Sedrotvorci, sedra i biodinamika, Krka i problemi njezine zaštite, Konzervatorski zavod NR Hrvatske, Zagreb

Polšak, M., Juriša, M., Šparica M., Šimunić, A., 1979, OGK 1:100.000, list Bihać, Savezni geološki zavod

Prelogović E. i ostali, 2001, Recentni strukturni sklop prostora Dinarida, INA-naftaplin, Zagreb (+ seizmotektonske karte M 1:200.000) 
Prelogović E. Alfirović B., Bahun S., 1999., Neotektonski odnosi područja s evaporitima imeđu Bihaća, Knina i Sinja. Arhiv INA - Naftaplin, Zagreb

Rogić, V., 1987, Geografska regionalizacija Jugoslavije, Veliki geografski atlas Jugoslavije (urednik I. Bertić), Sveučilišna naklada Liber, Zagreb

Roglić, J. 1951, Unsko-koranska zaravan i Plitvička jezera - geomorfološka promatranja, Geografski glasnik br. 13, GDH, Zagreb

Saletto - Janković, 1995., Geoekološke osobine NP Paklenica, Doktorska disertacija, Geografski odsjek PMF-a Zagreb, Zagreb

Sedra rijeke Une i Una bez sedre, naučna tribina, Bihać, 2000.

Spahić, M., 2000, Rijeka Una, potamološke karakteristike, naučna tribina, Bihać

Studija geoloških i inžinjerskogeoloških, hidrogeoloških i seizmotektonskih karakteristika terena i njihovog utjecaja na uslove prostornlog i urbanog planiranja na teritoriju opštine Bihać, Prostorni plan opštine Bihać, Institut za geotehniku, Sarajevo, 1985.

Studia o mogučnosti izgradnje HE Rmanj Manastir na rijeci Unac, 1986, Energoinvest, RO Energoinžinjering, OOUR Higrainžinjering, Sarajevo

Šušnjar, M., Bukovac, J., 1978, Osnovna geološka karta SFRJ - list Drvar, 1:100.000, Savezni geološki zavod, Beograd

Šušnjar, M., Bukovac, J., 1979, Tumač za list Drvar, Savezni geološki zavod, Beograd

Šušnjara A., Sakač K., Jelen B., Gabrić A., 1992, Upper Permian Evaporites and Associated Rocks of Dalmatia and Borderline Are Lika and Bosnia, Geologica Croatica, 45, Zagreb

Velić I., Bahun S., Sakač B., Galović J., 1974, Osnovna geološka karta, list Otočac 1:100.000, L 33 - 115, Institut za geološka istraživanja, Zagreb, Savezni geološki zavod, Beograd

Zaštita izvora rijeke Une, hidrogeološki i sanitarno-tehnički radovi, I. faza, INAprojekt, Odjel za geološka istraživanja, SIZ «Una-Sana», Tehnička arhiva br. 247, Zagreb, 1989.

Zaštita rijeke Unca-hidrogeološka sanitarno-tehnička ekspertiza, INAOOUR, Kompleksna geološka istraživanja, SIZ «Una - Sana», Tehnička arhiva br. 179, Zagreb, 1987. 


\title{
SAŽETAK
}

\section{Geomorfološke karakteristike gornjeg dijela doline Une između Martin Broda i Pritoke}

\begin{abstract}
Andrija Bognar
U svom gornjem toku Una protječe kroz karbonatne stjenske komplekse Vanjskih Dinarida. Geološka struktura i recentni tektonski pokreti bili su od odlučujućeg utjecaja na geomorfološko oblikovanje doline; tok Une od izvora do Bihaća prilagodio se primarnoj geološkoj strukturi i aktivnosti tektonskih pokreta. Dolina Une je kompozitna, karakterizirana izmjenom sutjeski, kotlina i zavala. Neusuglašeni uzdužni profil rijeke obilježen je brojnim brzacima, kaskadama, slapovima i vodopadima, čiji je nastanak prvenstveno uvjetovan akumulacijom sedre. Za taloženje sedre moraju postojati određeni uvjeti i to: voda mora sadržavati određenu količinu otopljenog kalcium bikarbonata, mora biti odgovarajuća temperatura vode tekućice, u vodama moraju egzistirati živi organizmi koji mogu zadržavati istaložene karbonate i mora postojati odgovarajuća brzina vode. Morfološka analiza utvrdila je da su se u koritu rijeke, zahvaljujući sedrenim akumulacijama, oblikovale brojne i veoma atraktivne reljefne forme: sedrene barijere, velike i male, sedreni sprudovi i otočići, spilje itd. Osim toga, korito karakterizira razvoj brojnih brzaka i kaskada te slapova i vodopada. To je posebno istaknuto kod Martin Broda i Štrbačkog buka, gdje su oblikovani najveći najljepši slapovi na rijeci.
\end{abstract}

Received (Primljeno): 2005 - 10 - 25

Accepted (Prihvaćeno): 2005 - 10 - 25

Andrija Bognar, Ph.D, full professor, Department of Geography, Faculty of Science, Marulićev trg 19, 10000 Zagreb Croatia/Hrvatska 